\title{
Toxicity Test of Catharanthus roseus Flower Extract with Brine Shrimp Lethality Test Method
}

\author{
Melia Sari ${ }^{1 *}$, Chemayanti Surbakti ${ }^{2}$, Tetty Noverita Khairani, Willy Novita Sari, \\ Gabriella Septiani Nasution ${ }^{3}$ \\ ${ }^{1}$ Department of Pharmaceutical Biology, Faculty of Pharmacy and Health, Institute for Health \\ Helvetia Medan, Indonesia \\ ${ }^{2}$ Department of Pharmaceutical Biology, Faculty of Pharmacy and Health, Universitas Sumatera \\ Utara, Medan, Indonesia \\ ${ }^{3}$ Health Analyst, Medical Laboratory Technology, Politeknik Kesehatan Kemenkes, Medan, \\ Indonesia \\ ${ }^{*}$ Corresponding author: \\ Email: meliasari@helvetia.ac.id
}

\begin{abstract}
.
Tapak dara (Catharanthus roseus) is a plant belonging to the Apocynaceae family originating from Central America and is generally grown as an ornamental plant. The purpose of this study was to determine the percentage of mortality data and the LC50 value of tapak dara methanol extract (Catharanthus roseus) against Artemia salina Leach larvae using the Brine Shrimp Lethality Test (BSLT) method. The BSLT method used consisted of 6 concentration treatments, namely 20 ppm, 60 ppm, 100 ppm, $140 \mathrm{ppm}, 180 \mathrm{ppm}$, and $0 \mathrm{ppm}$ a negative control, each of which was repeated three times. At each concentration, 10 experimental animals of 48 hours old Artemia salina Leach larvae were used. The toxic effect of the extract was identified by the percentage of mortality of Artemia salina Leach larvae using probit analysis (LC50). The results showed the linear regression equation $y=3.0809 x-12.065$. This shows that the mortality of the test animals reached $50 \%$ when the compound concentration reached 34,599 ppm. Based on the toxicity test of the methanol extract of the tapak dara flower (Catharanthus roseus) using the Brine Shrimp Lethality Test (BSLT) method, in this study it was toxic because LC50>1000 ppm so it has potential as an anticancer.
\end{abstract}

Keywords: Tapak dara (Catharanthus roseus), toxicity, BSLT

\section{INTRODUCTION}

Medicinal plants have long been used by the community in efforts to cure and prevent disease, increase endurance and restore fitness. Indonesia is a country that has a wealth of biodiversity, about 30 thousand species of plants in Indonesia, more than 1000 species have been used for treatment. Indonesia is very rich in medicinal ingredients derived from nature, almost every ethnic group in Indonesia has medicinal plants and ingredients typical of traditional medicines/native Indonesian medicines [1].

Traditional medicine is an ingredient or ingredient in the form of plant material, animal material, mineral material, preparation of extracts (galenic), or a mixture of these materials which have been used for generations for treatment, and can be applied in accordance with the prevailing norms in society [2]. 
Various research centers use the latest scientific methods to analyze biologically active ingredients [3]. Factors that must be considered in the analysis of active ingredients other than efficacy and quality are the safety of these traditional medicines in the use of herbal preparations as treatment [4].

One of the plants that are efficacious as medicine is the tapak dara plant (Catharanthus roseus). Tapak dara (Catharanthus roseus) is an important medicinal plant from the Apocynaceae family. Catharanthus roseus is a species endemic to Madagascar, has two types of flower colors, namely pink flowers "Catharanthus rosea" and white flowers "Catharanthus alba". In particular, Catharanthus roseus is an ornamental plant that produces more than 400 types of alkaloids that are potentially active as chemical elements, some of which exhibit strong and important pharmacological activities [5].

This plant has been reported to have efficacy in treating several types of diseases, even abroad, this tapak dara (Catharanthus roseus) has been processed into injectable drugs [6]. In Indonesia itself, it is reported that all parts of the plant can be used as treatment, starting from the roots, leaves, flowers as a diuretic, treating high blood pressure, lowering body heat, diabetes [7], and launching menstruation [8].

According to Verrananda (2016), in his research entitled "Identification of Secondary Metabolites and Antioxidant Activity of Tapak Dara Flower Extract (Catharanthus roseus)" stated that the phytochemical screening results contained alkaloids [9][10][11], flavonoids, phenolics, tannins and terpenoids [12][13]. And the secondary metabolite group with IC50 value in the tapak dara flower (Catharanthus roseus) shows the natural antioxidant activity as an antidote to free radicals [14]. Tapak dara also has the potential as an anti-herpes simplex type 1 agent [15].

Various studies have been conducted to examine the content and benefits of the tapak dara plant, including tapak dara has antihyperglycemic and hypoglycemic effects [16], antibacterial [17][18], antibacterial against Escherichia coli, Staphylococcus aureus, and Bacilus subtilis, and has antibacterial activity. high free radical inhibitors of about $87.7 \%$ at $200 \mathrm{~g} / \mathrm{ml}$ [19]. The alkaloids contained in this plant can induce relatively high glucose uptake in pancreatic TC6 or $\mathrm{C} 2 \mathrm{C} 12$ myoblast cells, as well as inhibit protein tyrosine in type II diabetes [20][21]. Tapak dara also contains indole monoterpenoid alkaloids (MIA) which are used in the treatment of cancer [22][23].

According to previous research conducted by Prasetyo (2016), it showed that the extract of tapak dara flower with concentrations of $60 \%, 70 \%, 80 \%, 90 \%, 100 \%$ showed the achievement of LC50 at a concentration of 91.2. The results showed that the higher the concentration of tapak dara flower extract used, the higher the concentration of Aedes aegyepti larvae mortality [24]. Based on the above considerations, the researchers wanted to determine the toxicity level of the methanol extract of the tapak dara flower (Catharanthus roseus) on Artemia salina larvae by looking at the LC50 value using the Brine Shrimp Lethality Test (BSLT) method. 


\section{METHODS}

Sampling in this study was purposive random sampling, that is, without comparing with similar plants from other areas. The sample used was taken from the City of Rantau Prapat, North Sumatra. The flower of tapak dara (Catharanthus roseus) was taken in the morning as much as $2.5 \mathrm{~kg}$, then wet sorting was carried out to separate dirt or other foreign materials and weighed. Furthermore, washing using running water is carried out to remove soil and other impurities attached to the simplicia material. After that, the drying process is carried out in a drying cabinet to obtain simplicia that is not easily damaged, so that it can be stored for a longer time, then in a blender to obtain simplicia powder [25].

The extraction method used was maceration with a ratio of 1:10 simplicia powder macerated for 5 days, $360 \mathrm{~g}$ of simplicia was put into a glass jar then soaked with $2,700 \mathrm{ml}$ of methanol solvent covered with aluminum foil for 3 days (stirring occasionally) and then filtered using filter paper. and obtained filtrate 1 and residue. The residue was soaked again using $900 \mathrm{ml}$ of methanol solvent for 2 days (stirring occasionally) then filtered using filter paper and obtained filtrate 2 and residue. The filtrate 1 and 2 were combined and then evaporated using a rotary evaporator at a temperature of 400C - 600C until a thick extract was obtained [26].

Manufacture of Artificial Seawater (ALB)

Artificial Seawater (ALB) was prepared by doing 150 grams of $\mathrm{NaCl}$ into 10 liters of aquadest. Then the seawater has first measured the $\mathrm{pH}$ using a $\mathrm{pH}$ meter, obtaining a pH of 8-9 [27].

\section{Shrimp Larva Hatching}

The hatching of shrimp larvae was carried out in the aquarium. Previously, the aquarium was divided into light and dark sections, then given a barrier in the form of styrofoam with a hole in the bottom edge so that the eggs that hatched could come out of the hole. The aquarium is then filled with seawater until the two holes in the styrofoam are submerged.

In a dark room filled with 1 egg spoon, then covered with black duct tape and aluminum foil. In a bright room, it is lit using fluorescent lamps to stimulate hatching. Then in the bright room, an aerator is installed to provide oxygen to the eggs that hatch into larvae and move to the bright room. After the eggs hatch into larvae that are 24 hours old, then they are transferred to another container until they are 48 hours old. The 48-hour-old larvae can be used as test animals in the BSLT method experiment [28].

\section{Preparation of Sample Solution to be Tested}

The mother liquor was made from 2 grams of extract that had been weighed and then dissolved with $2 \mathrm{ml}$ of DMSO and added with aquadest until the volume reached $1000 \mathrm{ml}$ so that the concentration of the mother liquor was $2000 \mathrm{ppm}$. After obtaining the mother liquor of $2000 \mathrm{ppm}$, dilution was carried out to obtain a test solution with a concentration of 20 ppm, 60 ppm, 100 ppm, 140 ppm, 180 ppm.

Toxicity Test Procedure with BSLT Method 
10 Artemia salina Leach larvae that were 48 hours old were put into a test tube and pipetted with the test solution with a dilution concentration of $20 \mathrm{ppm}, 60 \mathrm{ppm}$, $100 \mathrm{ppm}, 140 \mathrm{ppm}, 180 \mathrm{ppm}$. Then add it with seawater up to $10 \mathrm{ml}$. Each concentration was repeated 3 times and compared with the negative control. The number of dead larvae after 24 hours was counted in each test tube. Calculations are carried out using a magnifying glass or under lamp lighting. Dead larvae were identified from the absence of movement during observation [27].

Data Processing and Analysis

Analysis of data in determining the percentage of larval mortality for each concentration using Microsoft Office Excel by graphing a straight line equation of the relationship between the probit value and the concentration log. The LC50 value can be calculated from the straight-line equation by entering the value 5 as y. The value of 5 was obtained based on the probit value of $50 \%$ of the test animal mortality.

The $\mathrm{x}$ value is generated as the concentration log. The LC50 value is the antilog of the $x$ value. In the manual probit analysis method, the probit value is known by converting the percentage of larval mortality for each concentration to the probit value in the table by determining the concentration log and making a straight line equation $y$ $=\mathrm{mx}+\mathrm{b}$, where $\mathrm{y}$ is the probit value and $\mathrm{x}$ is the concentration $\log$ [27].

\section{RESULT AND DISCUSSION}

This study used the tapak dara flower (Catharanthus roseus) which was obtained from the garden of a resident of the Rantau Prapat area. Furthermore, the determination was carried out at the Herbarium Medanense (MEDA) University of North Sumatra with the result of the determination being the tread dara flower (Catharanthus roseus). The tapak dara flower (Catharanthus roseus) was extracted using methanol as a solvent, then filtered and evaporated using a rotary evaporator to evaporate the methanol solvent so that a thick extract of the tapak dara flower was obtained as much as 64.16 grams with a yield of $17.82 \%$.

The results of the percent yield explained that the bioactive levels in the extract were quite good for further testing, this was because the methanol solvent was polar so it had a better ability to dissolve the flavonoid compounds contained in the tapak dara flower [27].

The results of observations of Artemia salina Leach larvae after administration of methanol extract of tapak dara flower (Catharanthus roseus) with various concentrations after 24 hours can be seen in Table 1 .

Table 1. Effect of various concentrations of methanol extract of tapak dara flower (Catharanthus roseus) on Artemia salina Leach shrimp larvae

\begin{tabular}{ccccccc}
\hline & \multicolumn{4}{c}{ Artemia salina Leach Shrimp Larvae Mortality Rate } & \begin{tabular}{c} 
Negative \\
Control \\
\cline { 2 - 6 } Treatment
\end{tabular} & \multicolumn{4}{c}{ Konsentrasi (ppm) } & 0\% \\
\cline { 2 - 7 } & $\mathbf{2 0} \mathbf{~ p p m}$ & $\mathbf{6 0} \mathbf{~ p p m}$ & $\mathbf{1 0 0} \mathbf{~ p p m}$ & $\mathbf{1 4 0} \mathbf{~ p p m}$ & $\mathbf{1 8 0} \mathbf{~ p p m}$ & 0 \\
I & 2 & 6 & 7 & 9 & 10 & 0 \\
\hline II & 3 & 6 & 9 & 9 & 10 & 0 \\
\hline
\end{tabular}




\begin{tabular}{ccccccc}
\hline III & 5 & 8 & 10 & 9 & 10 & 0 \\
Total & 10 & 20 & 26 & 27 & 30 & 0 \\
Average Death & 0,33 & 0,66 & 0,86 & 0,9 & 1 & 0 \\
$\begin{array}{c}\text { Percentage of } \\
\text { Death } \%\end{array}$ & 33,33 & 66,66 & 86,66 & 90 & 100 & 0 \\
\hline
\end{tabular}

At concentrations of $20 \mathrm{ppm}, 60 \mathrm{ppm}, 100 \mathrm{ppm}, 140 \mathrm{ppm}, 180 \mathrm{ppm}$, and 0 ppm as negative controls, the total larval mortality was 10,20,26, 27, 30, 0 and the average mortality was $0.33,0.66,0.86,0.90,1.0$ with the percentage of deaths of $33.33 \%, 66.66 \%, 86.66 \%, 90 \%, 100 \%, 0 \%$ (can be seen in Table 2 ).

Table 2. Calculation of LC50 value of tapak dara flower extract (Catharanthus rosues) using probit analysis

\begin{tabular}{ccccccc}
\hline $\begin{array}{c}\text { Concentration } \\
(\%)\end{array}$ & ppm & $\begin{array}{c}\text { Log } \\
\text { Concentration } \\
(\mathbf{x})\end{array}$ & $\begin{array}{c}\text { Probit } \\
(\mathbf{y})\end{array}$ & \%Death & Mortality & Total \\
\hline 20 & 200000 & 5,301 & 4,56 & $33 \%$ & 10 & 30 \\
60 & 600000 & 5,778 & 5,44 & $67 \%$ & 20 & 30 \\
100 & 1000000 & 6,000 & 6,13 & $87 \%$ & 26 & 30 \\
140 & 1400000 & 6,146 & 6,28 & $90 \%$ & 27 & 30 \\
180 & 1800000 & 6,255 & 8,09 & $100 \%$ & 30 & 30 \\
\hline
\end{tabular}

In this study, it was found that the methanol extract of the tapak dara flower (Catharanthus roseus) has high effectiveness so it is toxic. The compounds contained in the tapak dara flower (Catharanthus roseus) are alkaloids, phenolics, flavonoids, terpenoids, and tannins [29], which at certain levels have toxic potential and can cause the death of Artemia salina Leach shrimp larvae. The mechanism of larval death is thought to be related to the alkaloid and flavonoid compounds in the henna that inhibit the larval feeding power (antifeedant).

The compound enters the larva's body, then the digestive tract will be disturbed so that this compound inhibits taste receptors in the larva's mouth area. This causes the larvae to fail to get a taste stimulus so they are unable to recognize their food and making the larvae starve to death. The phrase used in this study is the nauplius phase because at this phase Artemia salina Leach is in a very active phase of mitotic division which is identical to cancer cells which also divide mitotically. This is why the BSLT assay is often performed for a preliminary test of anticancer activity [27]. Tests have also been carried out on rats, the result is that extract concentrations $>300 \mathrm{mg}$ can produce biochemical and histopathological toxicity in the liver, kidneys, and heart [30].

The graph of the level of influence of concentration can be seen in Figure 1 . Shows the level of influence of the concentration of the methanol extract of the tapak dara flower (Catharanthus roseus) on the mortality of Artemia salina Leach larvae. The highest percentage of larval mortality was found at concentrations of $100 \mathrm{ppm}$, $140 \mathrm{ppm}$, and $180 \mathrm{ppm}$. While the lowest percentage level was found at a concentration of $20 \mathrm{ppm}$ and $0 \mathrm{ppm}$ as a negative control. 


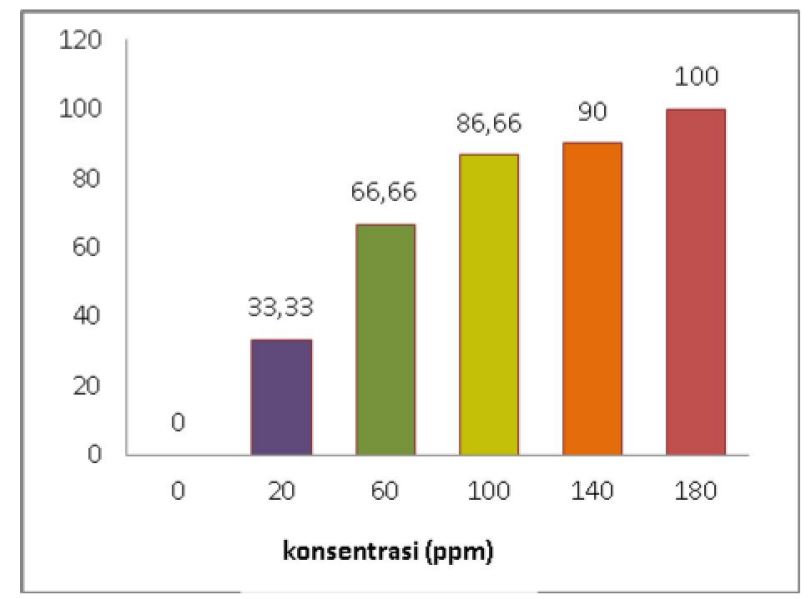

Fig. 1. Graph of the effect of the concentration of methanol extract of tapak dara flower (Catharanthus roseus) on Artemia salina Leach larvae

The relationship between the percentage of larval mortality and the extract can be seen from Figure 2 showing the relationship between the percentage of mortality of Artemia salina Leach larvae and the concentration log of the extract of the tapak dara flower (Catharanthus roseus). The linear regression equation from the graph above is $\mathrm{Y}=3.0809 \mathrm{x}-12.065$. So that the $\mathrm{X}$ value is 5.539075 , the LC50 value is articulated and gets a value of $34,599 \mathrm{ppm}$. This means that the mortality of the test animals reached $50 \%$ when the concentration of the compound extract reached $34,599 \mathrm{ppm}$.

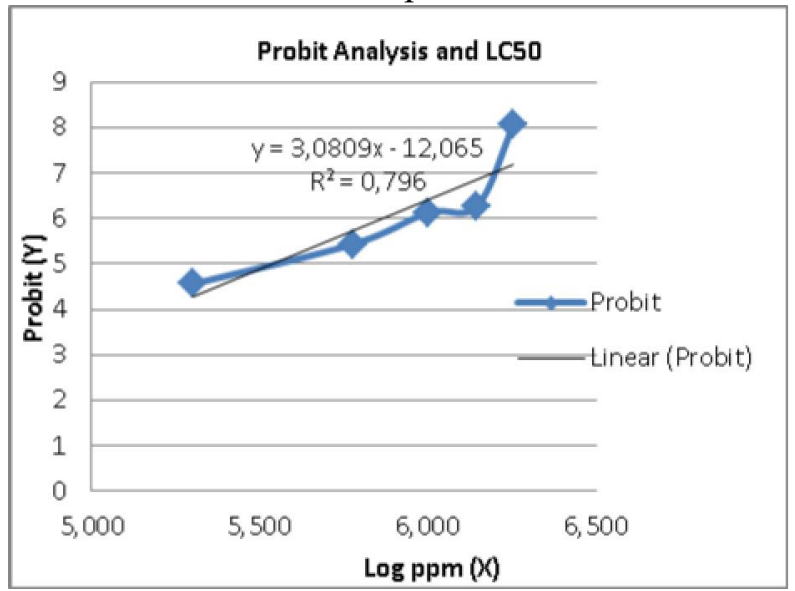

Fig. 2. Linear regression graph of extract concentration of tapak dara flower (Catharanthus roseus)

Based on the toxicity test of the methanol extract of the tapak dara flower (Catharanthus roseus) using the BSLT (Brine Shrimp Lethality Test) method in this study, it is toxic because $\mathrm{LC}_{50}<1000 \mathrm{~g} / \mathrm{ml}$ so it has potential as an anticancer [27]. According to Meyer (1982), reported that an extract showed toxic activity in BSLT if the extract caused the death of $50 \%$ of test animals at a concentration of less than 1000 
$\mathrm{g} / \mathrm{ml}$ [28]. Based on the statement above, the methanol extract of the tapak dara flower (Catharanthus roseus) is toxic. This is indicated by the data acquisition of methanol extract reaching $\mathrm{LC}_{50}$ at a concentration of $34,599 \mathrm{ppm}$.

\section{CONCLUSION}

The methanol extract of the tapak dara flower (Catharanthus roseus) has potential toxicity to Artemia salina Leach using the Brine Shrimp Lethality Test (BSLT) method. The $\mathrm{LC}_{50}$ value of the tapak dara flower (Catharanthus roseus) methanol extract determined by probit analysis was $34,599 \mathrm{ppm}$.

\section{ACKNOWLEDGMENTS}

The author would like to thank the Ministry of Education, Culture, Research, and Technology for providing the PDP Grant Fund to researchers so that this research can be completed properly.

\section{REFERENCES}

[1] BPOM RI, Acuan Sediaan Herbal Volume 7 Edisi 1. 2012.

[2] Kementerian Kesehatan RI, "Peraturan Menteri Kesehatan Republik Indonesia Nomor 61 tahun 2016 tentang Pelayanan Kesehatan Tradisional Empiris," Kementrian Kesehat. RI, no. 1994, 2016.

[3] B. Sudewo, Basmi Kanker Dengan Herba. Yogyakarta: Visimedia, 2012.

[4] Badan Pengawas Obat dan Makanan Republik Indonesia, Acuan Sediaan Herbal Volume 5 Edisi 1. 2010.

[5] M. Sain and V. Sharma, "Catharanthus roseus (An anti-cancerous drug yielding plant)A Review of Potential Therapeutic Properties," Int. J. Pure Appl. Biosci., vol. 1, no. 6, pp. 139-142, 2013, [Online]. Available: www.ijpab.com.

[6] A. Agoes, Tanaman Obat Indonesia. Jakarta: Salemba Medika, 2010.

[7] Yunilda Rosa and Aprilia Lestari, "Uji Efektivitas Ekstrak Daun Tapak Dara (Catharanthus roseus L.) Terhadap Penurunan Kadar Gula Darah Pada Tikus Putih Jantan Galur Wistar," J. Kesehat. J. Ilm. Multi Sci., 2018, doi: 10.52395/jkjims.v8i02.58.

[8] A. Almukarramah, I. Ibrahim, and S. Sufriadi, "Tanaman Berkhasiat Obat dari Sub Kelas Sympetaleae yang digunakan Masyarakat," Serambi Saintia J. Sains dan Apl., vol. 7, no. 1, 2019, doi: 10.32672/jss.v7i1.988.

[9] A. Sahay, A. Piprodhe, and M. Pise, "In silico analysis and homology modeling of strictosidine synthase involved in alkaloid biosynthesis in catharanthus roseus," $J$. Genet. Eng. Biotechnol., 2020, doi: 10.1186/s43141-020-00049-3.

[10] S. N. Pandey, V. Pratap, S. Pratap, and N. Kumar, "Phytochemicals and Pharmacological Studies of Catharanthus Roseus Linn-a Comprehensive Review," Surya al. World J. Pharm. Res., 2020.

[11] V. N. Fraser, B. Philmus, and M. Megraw, "Metabolomics analysis reveals both plant variety and choice of hormone treatment modulate vinca alkaloid production in Catharanthus roseus," Plant Direct, 2020, doi: 10.1002/pld3.267. 
[12] M. Sain and V. Sharma, "Catharanthus roseus (An anti-cancerous drug yielding plant)A Review of Potential Therapeutic Properties," Inteernational J. Pure Appl. Biosci., vol. 1, no. 6, pp. 139-142, 2013, [Online]. Available: www.ijpab.com.

[13] A. Sharma, D. Amin, A. Sankaranarayanan, R. Arora, and A. K. Mathur, "Present status of Catharanthus roseus monoterpenoid indole alkaloids engineering in homo- and hetero-logous systems," Biotechnology Letters. 2020, doi: 10.1007/s10529-019-027574.

[14] I. Verrananda M, V. Y. Fitriani, L. Febrina, and L. Rijai, "Identifikasi Metabolit Sekunder Dan Aktivitas Antioksidan Ekstrak Bunga Tapak Dara (Catharanthus roseus)," 2016, doi: 10.25026/mpc.v4i1.176.

[15] N. Z. A. Wahab, A. Azizul, and N. Ibrahim, "Phytochemistry, cytotoxicity and antiviral activity of catharanthus roseus," Iran. J. Microbiol., 2020, doi: 10.18502/ijm.v12i5.4608.

[16] "Jerald, Edwin et all. Comparative Evaluation of Antihyperglycamic and Hypoglycaemic Activity of Various Parts of Cantharanthus roseus Linn. 2008;2(1):10 5.".

[17] M. L. Raza, M. Nasir, T. Abbas, and B. S. Naqvi, “ Antibacterial activity of different extracts from the Catharanthus roseus ," Clin. Exp. Med. J., vol. 3, no. 1, pp. 81-85, 2009, doi: 10.1556/cemed.3.2009.1.7.

[18] I. H. Rahayuda, "Uji Aktivitas Antibakteri Fraksi Ekstrak Etanol Daun Tapak Dara (Catharanthus roseus (L.) G. Don) Terhadap Bakteri Staphylococcus aureus ATCC 25923 dan Staphylococcus aureus Isolat Klinis," Universitas Padjadjaran, 2015.

[19] A. M. Syeda and K. Riazunnisa, "Data on GC-MS analysis, in vitro anti-oxidant and anti-microbial activity of the Catharanthus roseus and Moringa oleifera leaf extracts," Data Br., 2020, doi: 10.1016/j.dib.2020.105258.

[20] S. H. Tiong et al., "Antidiabetic and antioxidant properties of alkaloids from Catharanthus roseus (L.) G. Don,” Molecules, 2013, doi: 10.3390/molecules18089770.

[21] S. N. Singh et al., "Effect of an antidiabetic extract of Catharanthus roseus on enzymic activities in streptozotocin induced diabetic rats," J. Ethnopharmacol., vol. 76, no. 3, pp. 269-277, 2001, doi: 10.1016/S0378-8741(01)00254-9.

[22] Y. Qu, O. Safonova, and V. De Luca, "Completion of the canonical pathway for assembly of anticancer drugs vincristine/vinblastine in Catharanthus roseus," Plant J., 2019, doi: 10.1111/tpj.14111.

[23] B. Larsen et al., "Identification of iridoid glucoside transporters in Catharanthus roseus," Plant Cell Physiol., 2017, doi: 10.1093/pcp/pcx097.

[24] E. Prasetio, "Pemanfaatan Ekstrak Bunga Tapak Dara (Catharanthus roseus sebagai Insektisida Alami Pembunuh Nyamuk Aedes aegepti," J. Chem. Inf. Model., vol. 53, no. 9, pp. 1689-1699, 2019.

[25] Departemen Kesehatan Republik Indonesia, Cara Pembuatan Simplisia. Jakarta: Departemen Kesehatan Republik Indonesia; 1985. 1985.

[26] P. O. M. Dirjen, Farmakope Indonesia Edisi III. 1979.

[27] N. Z. Hanifah, "Uji Toksisitas Akut Metanol Daun Sirsak (Annona muricata L) Terhadap Larva Artemia salina Leach Dengan Metode Brine Shrimp Lethality Test (BSLT)," 2015.

[28] B. N. Mayer, "Brine Shrimp: A Convenient General Bioassay for Active Plant 
Constituents," vol. 45, pp. 31-34, 1982.

[29] N. C. Rini, "Perbandingan fitokimia ekstrak daun dan ekstrak bunga tanaman tapak dara (Catharanthus roseus) dengan metode skrining," Universitas Katolik Widya Mandala, 2019.

[30] V. R. Vutukuri, M. C. Das, M. Reddy, S. Prabodh, and P. Sunethri, "Evaluation of acute oral toxicity of ethanol leaves extract of Catharanthus roseus in wistar albino rats,” J. Clin. Diagnostic Res., 2017, doi: 10.7860/JCDR/2017/24937.9325. 